\title{
First record of Cymatodiscus planetophorus (Bacillariophyta) for littorals of NW Mexico; ecological remarks
}

\section{Primer registro de Cymatodiscus planetophorus para litorales del noroeste de México y observaciones ecológicas}

\author{
Estrada-Gutiérrez, K. M. ${ }^{1 *}$, Hernández-Almeida, O. U. ${ }^{\circledR}$, Siqueiros-Beltrones, D. A. ${ }^{3}$, Flores-Ortega, J. R. ${ }^{4}$. \\ ${ }^{1}$ Programa de Doctorado en Ciencias Biológico Agropecuarias, Área de Ciencias Pesqueras, Unidad Académica \\ de Agricultura, Universidad Autónoma de Nayarit, Km. 9 Carretera Tepic-Compostela, CP. 63780, Xalisco, Nayarit, \\ México. 'Laboratorio de Oceanografía Biológica, Universidad Autónoma de Nayarit, Edificio CEMIC 01, Ciudad de \\ la Cultura "Amado Nervo", C.P. 63000, Tepic, Nayarit, México. ${ }^{3}$ Departamento de Plancton y Ecología Marina, Centro \\ Interdisciplinario de Ciencias Marinas, Instituto Politécnico Nacional, Av. IPN s/n, Col. Playa Palo de Santa Rita, C.P. \\ 23096, La Paz, Baja California Sur, México. ' Unidad Académica Escuela Nacional de Ingeniería Pesquera, Universidad \\ Autónoma de Nayarit, C.P. 63740, San Blas, Nayarit, México.
}

Cite this paper/Cómo citar este artículo: Estrada-Gutiérrez, K. M., Hernández-Almeida, O. U., Siqueiros-Beltrones, D. A., Flores-Ortega, J. R. (2022). First record of Cymatodiscus planetophorus (Bacillariophyta) for littorals of NW Mexico; ecological remarks. Revista Bio Ciencias 9, e1176. https://doi. org/10.15741/revbio.09.e1176

\section{A B S T R A C T}

As part of a floristic analysis of diatoms (Bacillariophyta) at Reserva de la Biosfera Marismas Nacionales in Nayarit, Mexico, Cymatodiscus planetophorus is recorded for the first time in the northwestern coasts of Mexico. Samples were collected from various substrata in estuarine wetlands in areas of production and fishing of pleasure oyster Crassostrea corteziensis and mullet Mugil curema, respectively. Specimens of $C$. planetophorus were successfully distinguished of Cymatotheca weissflogii based on meristic and morphological characteristics using optic microscopy. Their frequency and abundance on the

Article Info/Información del artículo

Received/Recibido: April 04 2021.

Accepted/Aceptado: February $14^{\text {th }} 2022$.

Available on line/Publicado: February $16^{\text {th }} 2022$.
RES U MEN

Cymatodiscus planetophorus (Bacillariophyta) se registra por primera vez en las costas del Noroeste de México, como parte de un análisis florístico de diatomeas de la Reserva de la Biosfera Marismas Nacionales en Nayarit, México. Se recolectaron muestras de varios sustratos en humedales estuarinos en áreas de producción y pesca de ostión de placer Crassostrea corteziensis y lisa Mugil curema. Los especímenes de C. planetophorus fueron discriminados de Cymatotheca weissflogii con base en sus características merísticas y morfológicas mediante microscopía óptica. Según su frecuencia en los sustratos examinados, se confirma el hábito bentónico/ticoplanctónico de este taxón. Mugil curema y $C$. corteziensis se agregan a la lista de consumidores de $C$. planetophorus; este último como nuevo sustrato. Asimismo, se proporcionan observaciones ecológicas complementarias.

${ }^{*}$ Corresponding Author:

Kathie Monserrat Estrada Gutiérrez. Programa de Doctorado en Ciencias Biológico Agropecuarias, Área de Ciencias Pesqueras, Unidad Académica de Agricultura, Universidad Autónoma de Nayarit, Km. 9 Carretera Tepic-Compostela, CP. 63780, Xalisco, Nayarit, México. Phone:+52(322) 100 6977. E-mail: kathie.gutierrez@uan.edu.mx 
inspected substrata confirm the benthic/tychoplanktic habit of this taxon. Both $M$. curema and $C$. corteziensis are added to the list of consumers of $C$. planetophorus; the latter also as a new substrate. Complementary ecological remarks are provided.

\section{KEY WORDS}

Diatoms, distribution, ecology, floristics, identification.

\section{Introduction}

Diatoms make up one of the most ecologically important and productive groups of microalgae in aquatic ecosystems (Maclntyre et al., 1996; Martínez et al., 2013; Popovich \& Guinder, 2013). Nevertheless, although being considered one of the better-known primary producers (Jeffrey et al., 1997), current research has shown that much is yet unknown considering taxonomy alone. In this way, floristic studies of benthic diatoms along the littorals of the Gulf of California have become more comprehensive, even though most include only localities from the Baja California Peninsula (López-Fuerte et al., 2010; Siqueiros-Beltrones et al., 2011; Siqueiros-Beltrones \& Argumedo-Hernández, 2015; López-Fuerte \& Siqueiros-Beltrones, 2016; SiqueirosBeltrones et al., 2017; Martínez \& Siqueiros-Beltrones, 2018), while other regions such as the continental coasts have been hitherto neglected.

In accordance with the above, in the protected area known as Reserva de la Biosfera Marismas Nacionales, Nayarit (RBMNN) the study of diatoms is still incipient (EstradaGutiérrez et al., 2017; Hernández-Almeida et al., 2019). This area exhibits a great variety of habitats, including alluvial plains, coastal lagoons, estuaries, and mangrove forests (Blanco-Correa et al., 2011), which are used as a refuge, feeding and reproduction area of birds, mammals, reptiles, amphibians, giving to the area a great biological relevance (CONANP, 2013).

Thus, hypothesized that a high taxonomic diversity of benthic diatoms is to be found in the area, as it has been recorded in other parts of the Mexican region (Siqueiros-Beltrones, 2002; Siqueiros-Beltrones et al., 2017), where a large part of the rich diatom flora has yet to be discovered, including possible new records of diatom taxa.

\section{PALABRAS CLAVE}

Diatomeas, distribución, ecología, florística, identificación.

\section{Introducción}

Las diatomeas conforman uno de los grupos de microalgas de mayor importancia ecológica en ambientes acuáticos (Maclntyre et al., 1996; Martínez et al., 2013; Popovich \& Guinder, 2013). A pesar de que son uno de los grupos de productores primarios mejor conocidos (Jeffrey et al., 1997), las investigaciones actuales muestran que, tan solo de sus aspectos taxonómicos, aún hay un gran vacío de información. Desde esta perspectiva, los estudios sobre florística de diatomeas bentónicas a lo largo de los litorales del Golfo de California han venido siendo más comprensivos, aunque la mayoría abarca solamente localidades en la península de Baja California (López-Fuerte et al., 2010; Siqueiros-Beltrones et al., 2011; Siqueiros-Beltrones \& Argumedo-Hernández, 2015; López-Fuerte \& SiqueirosBeltrones, 2016; Siqueiros-Beltrones et al., 2017; Martínez \& Siqueiros-Beltrones, 2018), mientras que otras áreas en costas continentales han sido hasta ahora soslayadas.

De acuerdo con lo anterior, el estudio de diatomeas en el área protegida Reserva de la Biosfera Marismas Nacionales, Nayarit (RBMNN) es aún incipiente (Estrada-Gutiérrez et al., 2017; Hernández-Almeida et al., 2019). Esta área exhibe una amplia variedad de hábitats que incluye planicies aluviales, lagunas costeras, estuarios y manglares (Blanco-Correa et al., 2011) que ofrecen refugio, sitios de alimentación y de reproducción para aves, mamíferos, reptiles y anfibios, lo que confiere relevancia biológica a esta zona (CONANP, 2013).

Así, se hipotetiza que en esta área se encontrará una elevada diversidad taxonómica de diatomeas bentónicas, tal y como se ha registrado en otras partes de las costas de México (Siqueiros-Beltrones, 2002; Siqueiros-Beltrones et al., 2017), para las cuales falta por registrar mucho de la rica flora diatomológica incluyendo nuevos registros taxonómicos de diatomeas bentónicas.

Recientemente, en los sistemas de manglar de la RBMNN, específicamente en áreas de producción y pesca de ostión de placer Crassostrea corteziensis (Hertlein, 1951) y de lisa Mugil curema (Valenciennes, 1836), un estudio de diatomeas bentónicas redituó abundantes especímenes de Cymatodiscus 
Recently, in the mangrove systems of RBMNN, specifically in areas of production and fishing of the pleasure oyster Crassostrea corteziensis (Hertlein, 1951) and mullet Mugil curema (Valenciennes, 1836), the survey for benthic diatoms yielded a significant number of specimens of Cymatodiscus planetophorus (Meister) Hendey 1958, hitherto unrecorded for the Mexican region. Therefore, this study aimed to provide the first record of this taxon for Mexican coasts, particularly in the NW littorals. Meristic and morphometric traits were used to successfully discriminate Cymatodiscus planetophorus from Cymatotheca weissflogii (Grunow) Hendey 1958 using optic microscopy. Complementary ecological remarks on $C$. planetophorus are provided in order to discuss its ecological potential.

\section{Material and Methods}

\section{Study area}

Samples were collected at two estuarine flow planetophorus (Meister) Hendey 1958. A la fecha, este taxón no había sido registrado para México. De ahí que el objetivo de este estudio es proporcionar el primer registro de esta especie en costas mexicanas, y particularmente para los litorales del noroeste. Para identificar los especímenes de C. planetophorus, discriminándolos eficientemente de Cymatotheca weissflogii (Grunow) Hendey 1958, se utilizaron caracteres merísticos y morfométricos observados con microscopía óptica. Aunado a lo anterior, se incluyen observaciones ecológicas sobre $C$. planetophorus con el fin de discutir su potencial ecológico.

\section{Material y Métodos}

\section{Área de estudio}

La recolección de muestras se llevó a cabo en dos humedales estuarinos bordeados por manglar (Figura 1) los cuales se localizan dentro de la RBMNN: 1) Pozo Chino $\left(21^{\circ} 42^{\prime} 10.87^{\prime \prime} \mathrm{N}, 105^{\circ} 28^{\prime} 0.95^{\prime \prime} \mathrm{W}\right)$, un estuario angosto de fondo somero (<6 m) que es destinado al cultivo de ostión;

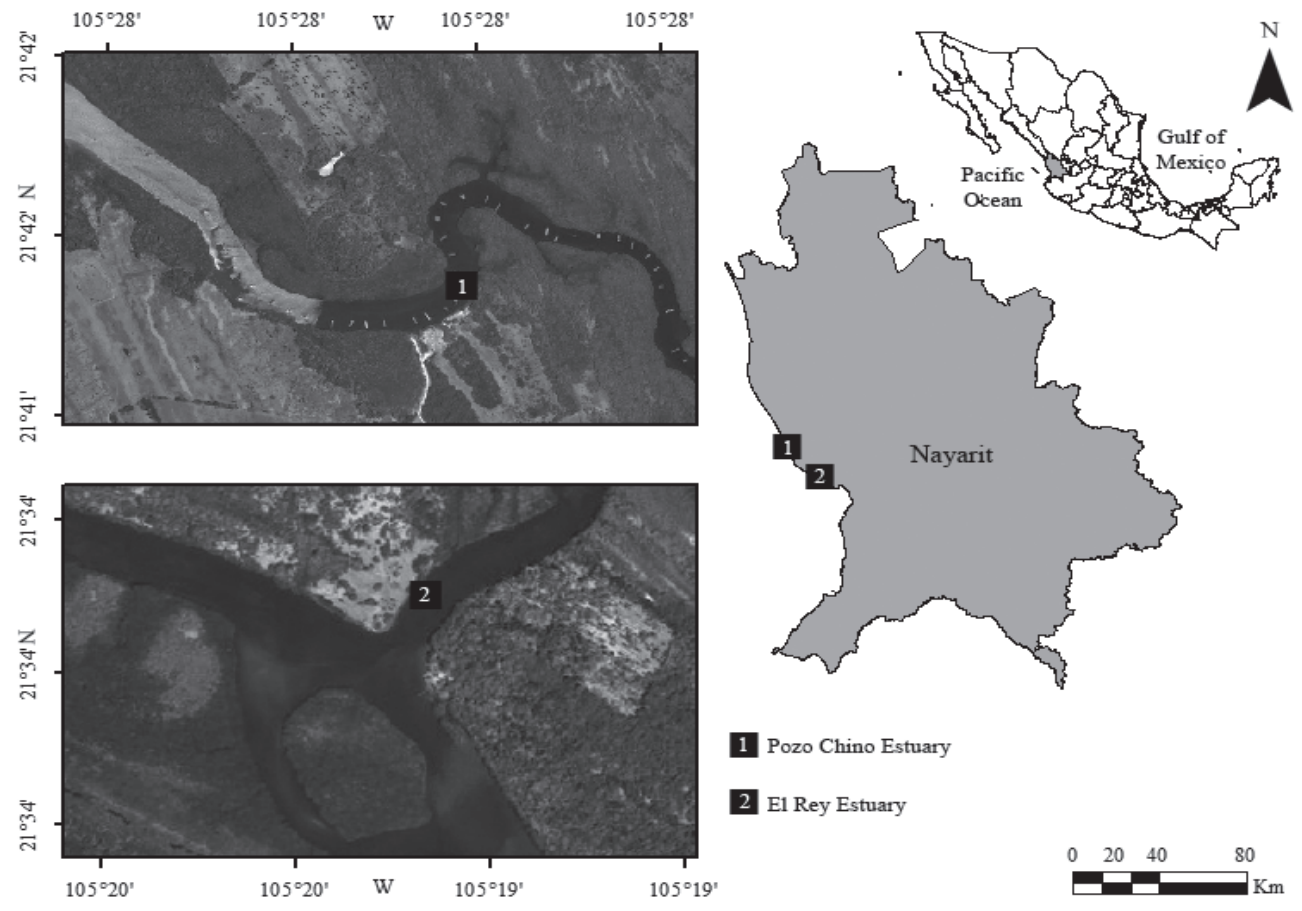

Figure 1. Location of study area and sampling sites.

Figura 1. Localización del área de estudio y sitios de recolecta de muestras. 
wetlands fringed by mangroves (Figure 1) located within the RBMNN: 1) Pozo Chino $\left(21^{\circ} 42^{\prime} 10.87^{\prime \prime} \mathrm{N}\right.$, $\left.105^{\circ} 28^{\prime} 0.95^{\prime \prime} \mathrm{W}\right)$, a narrow and shallow (<6 m) estuary, used in oyster culture; 2) El Rey $\left(21^{\circ} 33^{\prime} 51.30^{\prime \prime} \mathrm{N}\right.$, $\left.105^{\circ} 19^{\prime} 30.30^{\prime \prime} \mathrm{W}\right)$, which is part of a larger estuary used for fishing, that varies from 1-9 $\mathrm{m}$ in depth (BlancoCorrea et al., 2011; SAGARPA-CONAPESCA, 2010).

\section{Samplings}

At Pozo Chino estuary, samples were obtained monthly from different substrates from August 2017 to July 2018. Randomly, 120 oysters of Crassostrea corteziensis from suspended strings used in the commercial culture, were collected. Shells were removed from 10 oysters and their soft tissue was placed together in $10 \%$ formaldehyde (one composed-sample per month). Likewise, 12 sediment samples were collected (one per month) by scuba using a PVC nucleator $(2 \mathrm{~cm}$ height $x$ $5 \mathrm{~cm}$ diameter), placed in plastic bags, and transported in ice to the laboratory. Simultaneously, 12 surface water samples (one per month) were collected using $1000 \mathrm{~mL}$ PET bottles and fixed with $4 \%$ formaldehyde. Only the shells of the oysters collected in July were transported to the laboratory. Surface temperature and conductivity were measured using a $\mathrm{HOBO} \otimes$ U24 sensor only from November 2017 to July 2018. At El Rey estuary 4 specimens of mullet Mugil curema were gathered from the commercial trade (October 2016) and transported in ice to the lab. No environmental observations were made.

\section{Sample processing}

Contents from the digestive tracts of oysters and fish were retrieved by dissection. Water samples had scarce diatoms so monthly samples were combined for phytoplankton analysis. From the inverted PVC nucleator sediments of the first $0.5 \mathrm{~cm}$ were separated with a spatula. The convex surface of each oyster shell was brushed (toothbrush) while rinsing with distilled water. Frustules of diatoms present in samples of the digestive tract of oysters and fish (diatoms in the digestive tract), phytoplankton (planktonic diatoms), sediment (epipelic diatoms) and shell surface (epizoic diatoms), were cleaned using a modification of Siqueiros-Beltrones \& Voltolina (2000) technique, in which organic matter was oxidized with nitric acid, sulfuric acid, and commercial alcohol at a ratio of 3:2:1. The oyster shells brushed-off material and sediment samples were first treated with $10 \%$ hydrochloric acid to eliminate calcium carbonates.

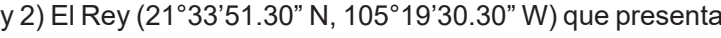
una profundidad de entre 1 y $9 \mathrm{~m}$, y el cual es parte de un estuario mayor en donde se practica la pesca (BlancoCorrea et al., 2011; SAGARPA-CONAPESCA, 2010).

\section{Muestreos}

En el estuario Pozo Chino se obtuvieron muestras mensuales de distintos sustratos desde agosto, 2017 a julio, 2018. Aleatoriamente se recolectaron 120 ostiones (Crassostrea corteziensis) de sartas suspendidas utilizadas en el cultivo comercial. Se retiró la concha de 10 ostiones y los tejidos blandos se conservaron juntos en formol al $10 \%$ (una muestra compuesta por mes). Mediante buceo libre, se recolectaron 12 muestras de sedimentos (una por mes) con un nucleador de PVC $(2 \mathrm{~cm}$ de alto $\times 5 \mathrm{~cm}$ de diámetro), las cuales se guardaron en bolsas de plástico y se transportaron en hielo al laboratorio. También, se recolectaron 12 muestras de agua superficial (una por mes) con botellas PET de $1000 \mathrm{~mL}$ y se fijaron con formol al $4 \%$. Asimismo, solo las conchas de los ostiones recolectados en julio se transportaron al laboratorio. Se midió la temperatura y conductividad del agua utilizando un sensor $\mathrm{HOBO} \otimes$ U24 solamente entre noviembre, 2017 y julio, 2018. En el estuario El Rey se obtuvieron 4 especímenes de lisa (Mugil curema) de la pesca comercial (octubre, 2016), que fueron transportados en hielo al laboratorio. En este caso no se hicieron observaciones ambientales.

\section{Procesamiento de muestras}

Los contenidos de tractos digestivos de ostiones y peces se extrajeron mediante disección. Debido a que las muestras de agua presentaron pocas diatomeas, las muestras mensuales se combinaron para el análisis de fitoplancton. Del nucleador invertido se separaron sedimentos de los primeros $0.5 \mathrm{~cm}$ mediante una espátula. La superficie convexa de cada concha de ostión se cepilló (cepillo dental) mientras se recuperaba la muestra con agua destilada. Las frústulas de las diatomeas presentes en las muestras de tracto digestivo de ostiones y peces (diatomeas en el tracto digestivo), fitoplancton (diatomeas planctónicas), sedimento (diatomeas epipélicas) y cepillado de conchas (diatomeas epizoicas), fueron limpiadas utilizando la técnica modificada de SiqueirosBeltrones \& Voltolina (2000); esta consiste en oxidar la materia orgánica con ácido nítrico, ácido sulfúrico, y alcohol comercial en proporción de 3:2:1. En el caso del cepillado de conchas y sedimentos, primero se hizo un tratamiento con ácido clorhídrico al $10 \%$ para eliminar el carbonato de calcio. Una vez oxidadas, las muestras se enjuagaron repetidamente con agua destilada hasta alcanzar un pH mínimo de 6 . 
Samples were then rinsed with distilled water until reaching a minimum $\mathrm{pH}$ of 6 .

Once cleaned, frustules of diatoms were mounted into permanent slides in Pleurax $®(I . R .=1.7)$. These preparations were used for qualitative and quantitative analysis of diatoms under a Carl Zeiss $\mathrm{GmBh}$ microscope (B) at $100 \times, 400 \times$ and $1000 \times$ equipped with phase contrast illumination and integrated camera. In each permanent slide a route was made that began in one of the margins to the opposite end and microphotographs of 50 specimens of C. planetophorus were taken. Each specimen was measured in valval view with Photoshop CS6 ${ }^{\circledR}$ using a calibrated-programed scale, calculated from micrographs captured in a calibration slide (Motic $®$ ) with the $0.07 \mathrm{~mm}$ magnitude at $1000 \times$. Thereby, data were collected from the main meristic (areolas and fultortulas in $10 \mu \mathrm{m}$ ) and morphometric (length, width, shape of the valve) characters of the species. Finally, to estimate the relative abundance of $C$. planetophorus in the diatom assemblages from the different type of substrate, 500 valves were counted overall, except in the phytoplankton samples.

Identification of $C$. planetophorus was based on Hendey (1958: Plate V, Figure 8) original description and other references: Desikachary et al. (1987: Plate 265, Figure 16, 371), Ricard (1987: 162, Figure 154), Foged (1975: Plate VII, Figure 10-11), Paulmier, (1993: Plate 35, Figure 7-8), Tremarin et al. (2008: 1107, Figure 1-2) and Lehmkuhl et al. (2010: 320, Figure 26). Also, the data base on www. algaebase.org (Guiry \& Guiry, 2021) was consulted to update the taxonomic nomenclature.

\section{Results} 1958 (Figures 2-6)

Cymatodiscus planetophorus (Meister) Hendey

\section{Meristics and morphometrics characteristics}

Valve elliptic, slightly depressed in the central area. Size range was 16.4-22.9 $\mu \mathrm{m}$ length, 12.1-16.6 $\mu \mathrm{m}$ wide, with 15-20 areolae in $10 \mu \mathrm{m}$ and 1-3 fultoportulae in 10 $\mu \mathrm{m}$ (Table 1). The smallest specimens of $C$. planetophorus (Figure 2) were found on the shells of oysters, and the larger (Figure 6 ) in the sediments and plankton. Plankton specimens had the lowest number of areolae (15 areolae in $10 \mu \mathrm{m})$. And only one specimen found on an oyster shell showed 3 fultoportulae in $10 \mu \mathrm{m}$ (Figure 3). Other distinctive
Una vez limpias, las frústulas de las diatomeas se montaron en preparaciones permanentes con la resina sintética Pleurax $\AA(I . R .=1.7)$. Estas preparaciones se utilizaron para el análisis cualitativo y cuantitativo de diatomeas utilizando un microscopio Carl Zeiss $\mathrm{GmBh} \circledast$ a $100 \times, 400 \times$ y $1000 \times$ equipado con contraste de fases y cámara integrada. Para ello, se realizó un recorrido que inició en uno de los márgenes del portaobjetos hasta el extremo opuesto y se tomaron microfotografías de 50 especímenes de C. planetophorus. Cada espécimen se midió en vista valvar en el programa Photoshop CS6 $₫$ usando una escala de medida calibrada y programada a partir de microfotografías tomadas en un portaobjetos de calibración (Motic®) con la medida de $0.07 \mathrm{~mm}$ a 100x. Así, se recabaron datos de los principales caracteres merísticos (areolas y fultopórtulas en $10 \mu \mathrm{m}$ ) y morfométricos (largo, ancho, forma de la valva) de la especie. Finalmente, para estimar la abundancia relativa de $C$. planetophorus en las asociaciones de diatomeas de los diferentes sustratos, se realizó un conteo de 500 valvas en total, excepto en las muestras de fitoplancton debido a la baja abundancia de diatomeas que se observaron.

La identificación de C. planetophorusse se basó en la descripción original de Hendey (1958: Lám. V, Figura 8) y otras referencias: Desikachary et al. (1987: Lám. 265, Figura 16, 371), Ricard (1987: 162, Figura 154), Foged (1975: Lám. VII, Figura 10-11), Paulmier, (1993: Lám. 35, Figura 7-8), Tremarin et al. (2008: 1107, Figura 1-2), y Lehmkuhl et al. (2010: 320, Figura 26). También se consultó la base de datos en www.algaebase.org (Guiry \& Guiry, 2021) para actualizar la nomenclatura taxonómica.

\section{Resultados} 1958 (Figuras 2-6)

Cymatodiscus planetophorus (Meister) Hendey

\section{Características merísticas y morfométricas}

Valvas elípticas ligeramente deprimidas en el área central. Su tamaño varió entre 16.4-22.9 $\mu \mathrm{m}$ de largo y 12.1-16.6 $\mu \mathrm{m}$ de ancho; presentó 15-20 areolas en $10 \mu \mathrm{m}$ y 1-3 fultopórtulas en $10 \mu \mathrm{m}$ (Tabla 1). Los especímenes más pequeños de $C$. planetophorus (Figura 2) se encontraron sobre conchas de ostiones y los más grandes (Figura 6) en sedimentos y plancton. Estos últimos presentaron el menor número de areolas (15 areolas en $10 \mu \mathrm{m}$ ); y solo un espécimen hallado sobre concha de ostión presentó 3 

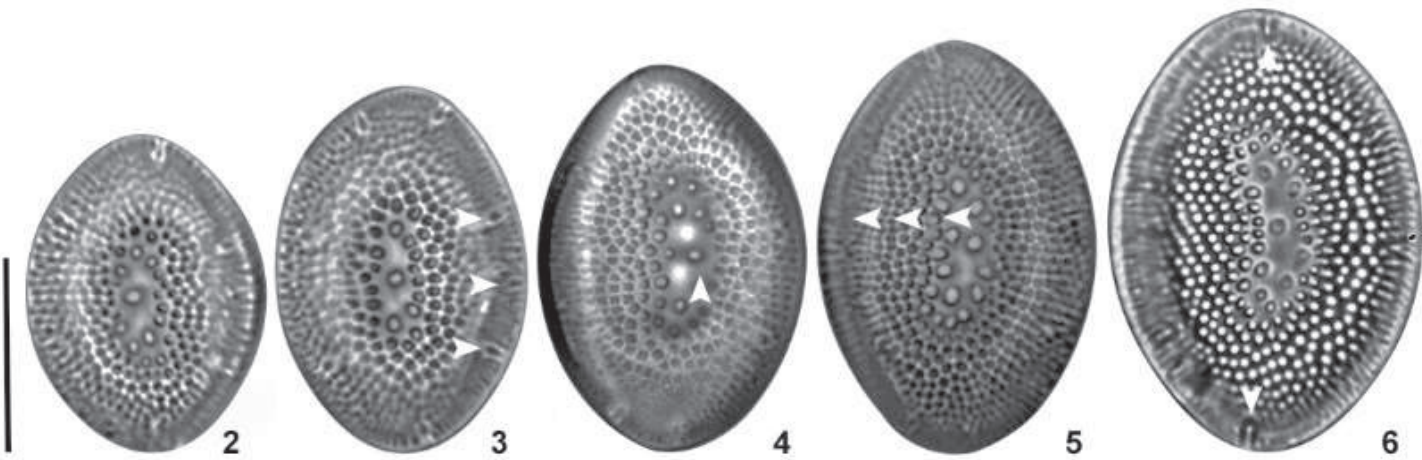

Figures 2-6. Various sizes of Cymatodiscus planetophorus. 2) Internal valve view, showing the smaller size in this study. 3) Internal valve view, showing three fultoportulae (arrows). 4) External valve view, showing the hyaline zone in the center of the valve (arrow). 5) Detail of the linear areolae becoming smaller towards the valval margins (arrows). 6) External valve view, showing the marginal ring of fultoportulae (arrows) and the bigger size to this study. Scale bar $=10 \mu \mathrm{m}$.

Figuras 2-6. Diversos tamaños de Cymatodiscus planetophorus. 2) Cara interna de la valva, mostrando el tamaño más pequeño que se observó en este estudio. 3) Cara interna de la valva, mostrando tres fultopórtulas (puntas de flecha). 4) Cara externa de la valva, mostrando la zona hialina en el centro de la valva (punta de flecha). 5) Detalle de las areolas lineales que disminuyen en tamaño conforme se acercan al margen de la valva (puntas de flecha). 6) Cara externa de la valva, mostrando el anillo marginal de fultopórtulas (puntas de flecha), así como el tamaño más grande que se observó en este estudio. Escala $=10 \mu \mathrm{m}$.

Table 1.

Comparison between meristic and morphometric traits of Cymatodiscus planetophorus collected in the wetlands of Nayarit, Mexico and other studies.

Tabla 1.

Comparación de características merísticas y morfométricas entre Cymatodiscus planetophorus recolectado en humedales de Nayarit, México y otros estudios.

\begin{tabular}{llcccc}
\hline \multicolumn{1}{c}{ Reference } & Type of sample & Length $(\boldsymbol{\mu m})$ & Width $(\boldsymbol{\mu m})$ & $\begin{array}{c}\text { Areolae } \\
(\mathbf{1 0} \boldsymbol{\mu m})\end{array}$ & $\begin{array}{c}\text { Fultoportulae } \\
(\mathbf{1 0} \boldsymbol{\mu m})\end{array}$ \\
\hline Hendey (1958) & Sediment & 24 & 16 & $6-12$ & $1-2$ \\
Bainbridge (1963) & Plankton & $17-24$ & n.d. & n.d. & n.d. \\
& DT/Echinoderm & $17-24$ & n.d. & n.d. & n.d. \\
Paulmier (1993) & Plankton & 25 & 17 & $11-12$ & n.d \\
Tremarin et al. (2008) & Plankton & $17.4-26.1$ & $12.6-17.4$ & $11-16$ & 2 \\
& Epiphyte & $17.4-26.1$ & $12.6-17.4$ & $11-16$ & 2 \\
Lehmkuhl et al. (2010) & Plankton & $12-26$ & $10-22$ & $12-20$ & $1-2$ \\
This study & Sediment & $17.3-22.9$ & $12.1-16.6$ & $17-20$ & 2 \\
& DT/Oyster & $16.5-22.8$ & $12.1-15.5$ & $16-19$ & $1-2$ \\
& DT/Fish & $16.9-21.9$ & $12.3-14.2$ & $17-20$ & 2 \\
C. weissflogii & Plankton & $17.3-22.8$ & $12.6-15.1$ & $15-20$ & 2 \\
\hline
\end{tabular}

n.d. = undetermined, DT = digestive tract content.

n.d. $=$ no determinado, $\mathrm{CT}=$ contenido de tracto digestivo. 

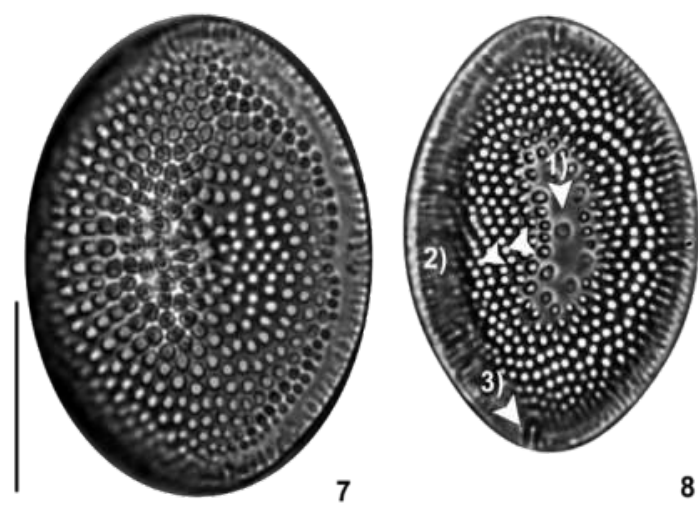

Figures 7-8. Internal valve view of Cymatotheca weissflogii. 8) Internal valve view of Cymatodiscus planetophorus showing the morphological characteristics that make it different from $\mathrm{C}$. weissflogii (arrows); 1) hyaline central zone with 1 to $3-4$ areolae; 2 ) radial areolae that become smaller towards the valve margins; 3 ) marginal ring of fultoportulae, usually two at each pole and two on the margin equidistant from the poles Scale bar $=10 \mu \mathrm{m}$.

Figuras 7-8. Cara interna de la valva de Cymatotheca weissflogii. 8) Cara interna de la valva de Cymatodiscus planetophorus mostrando las características morfológicas que la hacen distinta de C. weissflogii (puntas de flechas); 1) zona hialina en el centro de la valva con 1 o 3-4 areolas; 2) areolas que disminuyen en tamaño conforme se acercan al margen de la valva; 3 ) anillo marginal de fultopórtulas, generalmente dos en cada polo y dos en el margen equidistante de los polos. Escala $=10 \mu \mathrm{m}$.

traits of this taxon, that also discriminate between $C$. planetophorus from $C$. weissflogii, were a hyaline zone in the center of the valve (Figure 4), linear areolae becoming smaller towards the valval margins (Figure 5), and marginal ring of fultoportulae (Figure 6). These morphological characteristics differentiate $C$. planetophorus from $C$. weissflogii (Figures 7, 8).

\section{Ecological remarks}

The specimens of $C$. planetophorus were collected in the shallow coastal zone (3-9 m) of both wetlands of Nayarit, as epipelic, epizoic, and planktonic, as well as in the digestive tract of $C$. corteziensis and M. curema (Table 1). At Pozo Chino estuary the taxon was present during all sampling periods at temperatures between $23.3-31.8{ }^{\circ} \mathrm{C}$ and a salinity range of 21.1-33. The highest abundances were reached in October 2017 and March 2018 in the sediment at temperature intervals between 26.5$31.8^{\circ} \mathrm{C}$ and salinity of $25.8-33$. At El Rey estuary, C. planetophorus ocurred in October 2016 in the digestive tract of M. curema (Figure 9). fultopórtulas en $10 \mu \mathrm{m}$ (Figura 3). Las características que permiten discriminar este taxón de $C$. weissflogii fueron una zona hialina en el centro de la valva (Figura 4), areolas lineales que disminuyen su tamaño hacia los márgenes valvares (Figura 5), y un anillo marginal de fultopórtulas (Figura 6). Estas características morfológicas diferencian a C. planetophorus de C. weissflogii (Figuras 7, 8).

\section{Observaciones ecológicas}

Los especímenes de $C$. planetophorus se recolectaron en zonas someras (3-9 m) de ambos humedales de Nayarit y se encontraron como formas epipélicas, epizoicas y planctónicas, así como en tractos digestivos de $C$. corteziensis y $M$. curema (Tabla 1). En el estuario Pozo Chino el taxón estuvo presente en todo el periodo de muestreo en un intervalo de temperatura entre 23.3-31. ${ }^{\circ} \mathrm{C}$ y de $21.1-33$ de salinidad. En el sedimento, las mayores abundancias se alcanzaron en octubre de 2017 y marzo de 2018, en intervalos de temperatura entre 26.5-31. ${ }^{\circ} \mathrm{C}$ y salinidad de 25.8-33. En el estuario El Rey, C. planetophorus se presentó con mayor frecuencia y abundancia en octubre de 2016 en el tracto digestivo de $M$. curema (Figura 9). 


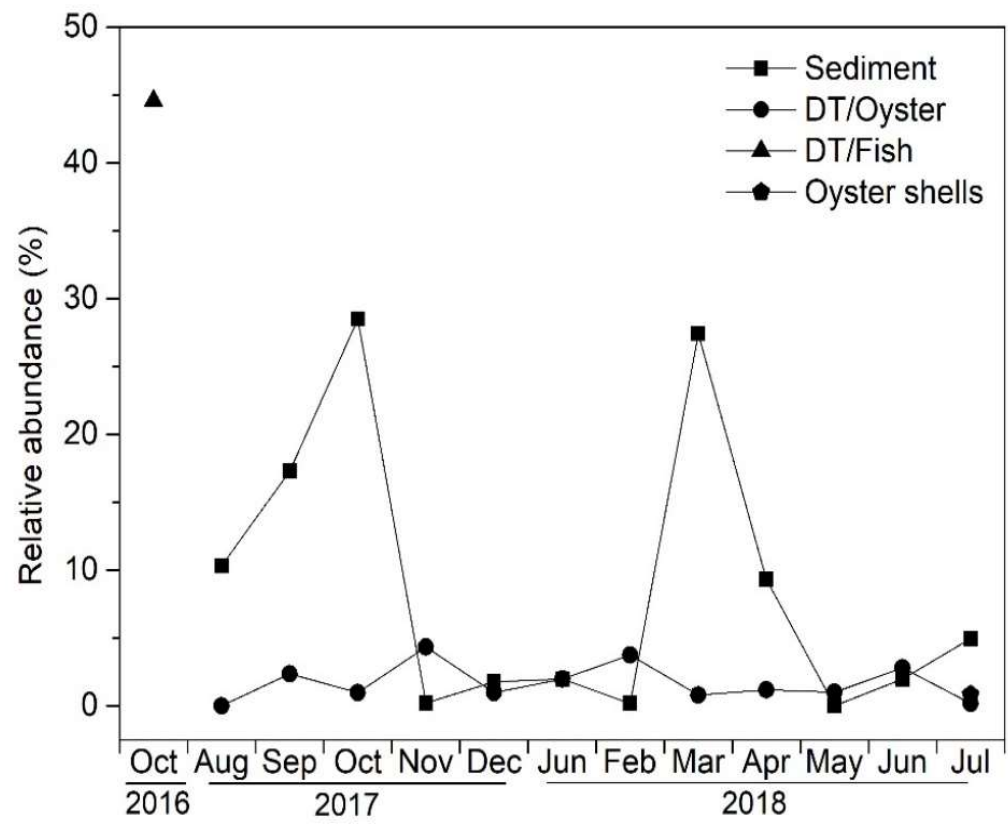

Figure 9. Relative abundance of Cymatodiscus planetophorus in the different substrates in which it was found. DT = digestive tract content.

Figura 9. Abundancia relativa de Cymatodiscus planetophorus en los diferentes sustratos en los que se encontró. CT = contenido de tracto digestivo.

\section{Discussion}

The first-ever description of C. planetophorus comprised specimens from the coast of Sierra Leona, Africa, but ever since, this taxon has been recorded in other tropical regions. For the Mexican region, a single potential record of the genus Cymatodiscus Hendey 1958 (Siqueiros-Beltrones \& Hernández-Almeida, 2006) shows a single image of a specimen found as epiphyte of Laurencia johnstonii Setchell \& N.L. Gardner 1924. However, said image does not show the details clearly enough, so there is no certainty on its identification. On the other hand, two previous studies on diatoms carried out in the area (RBMNN) specifically at Boca of Camichin estuary by Estrada-Gutiérrez et al. (2017) and Hernández-Almeida et al. (2019), did not record the presence of $C$. planetophorus. However, it should be noted that, in these studies, only samples of gut contents of $C$. corteziensis were inspected, unlike in this study that other types of samples (phytoplankton, oyster shells, sediment) were considered. Likewise, our results show that the highest abundances of $C$.

\section{Discusión}

La descripción original de C. planetophorus fue realizada con especímenes de la costa de Sierra Leona, África, pero desde entonces este taxón ha sido frecuentemente registrado en otras regiones tropicales. Para la región de México existe un solo registro potencial del género Cymatodiscus Hendey 1958 (Siqueiros-Beltrones \& Hernández-Almeida, 2006) que muestra una sola imagen de un especímen recolectado sobre la macroalga Laurencia johnstonii Setchell \& N.L. Gardner 1924 Desafortunadamente, dicha imagen no muestra detalles claros que permitan su identificación con certidumbre. Por otro lado, en dos estudios previos de diatomeas bentónicas llevados a cabo en el área (RBMNN), específicamente en el estuario Boca de Camichín (Estrada-Gutiérrez et al., 2017; Hernández-Almeida et al., 2019), no se registró la presencia de C. planetophorus. Sin embargo, es preciso señalar que, en los estudios anteriores solo se revisaron muestras de contenidos intestinales de $C$. corteziensis, a diferencia de este estudio que se consideraron otro tipo de muestras (fitoplancton, conchas de ostiones, sedimento). Además, nuestros resultados muestran que las mayores 
planetophorus were recorded in sediments, which had no correspondence with the abundances recorded in the digestive tract of oysters (Figure 9). Therefore, the fact that C. planetophorus was not found at Boca de Camichin could be related to the type of sample that was used and even to the food preferences of oyster. Kasim \& Mukai (2009) determined that this bivalve have in situ food preference for some species of microalgae.

In relation to the taxonomic difficulties facing this taxon, C. planetophorus was initially determined as Coscinodiscus planetophorus Meister (Hendey, 1958), which in turn was frequently mistaken for Coscinodiscus asymmetricus Meister. Detailed examination of both species resulted in the determination of distinct genera for these taxa: Cymatodiscus planetophorus (Meister) Hendey 1958 and Cymatotheca weissflogii (Grunow) Hendey 1958. Both have an elliptic valve and are similar in size (Table 1); however, characteristics that separate C. planetophorus from $C$. weissflogii are hyaline central zone with 1 to 3-4 areolae, radial areolae that become smaller towards the valve margins and a marginal ring of fultoportulae, usually two at each pole and two on the margin equidistant from the poles (Figures 7,8 ). These meristic and morphometrics differences are clearly distinguishable under light microscopy and allow to discriminate between the two taxa with certainty.

The ranges in morphometric and meristic values of the examined specimens in this study agree with those reported elsewhere (Table 1), although no specimens as small (12 $\mu \mathrm{m}$ in length) as those reported by Lehmkuhl et al. (2010: 320, Figure 26) were found, nor as big (23$30 \mu \mathrm{m}$ in length) as in Hendey (1958: Plate V, Figure 8), Paulmier (1993: Plate 35: Figure 7-8), or Tremarin et al. (2008: 1107, Figure 1-2).

Most reports on the habits of $C$. planetophorus refer it as a planktonic form, e.g., Bainbridge (1963), Desikachary et al. (1987), Ricard (1987), Paulmier (1993), Lin \& Yan (2007), Tremarin et al. (2008), Lehmkuhl et al. (2010), Costa-Böddeker et al. (2016) and Parizzi et al. (2016). But it has also been reported as epipelic (Hendey,1958; Sylvestre et al., 2004; Costa-Böddeker et al., 2016) and as epiphyte (Foged, 1975; Sylvestre et al., 2004; Tremarin et al., 2008). Sylvestre et al. (2004) considered C. planetophorus a benthic form, as well as abundancias de $C$. planetophorus se registraron en sedimentos, las cuales no tuvieron correspondencia con las abundancias registradas en el tracto digestivo de ostiones (Figura 9). Por lo tanto, el hecho de no haber encontrado a C. planetophorus en Boca de Camichín podría estar relacionado con el tipo de muestra que se utilizó e incluso con las preferencias alimentarias del ostión. Al respecto, Kasim \& Mukai (2009) determinaron que estos bivalvos presentan preferencia alimentaria in situ por algunas especies de microalgas.

Respecto a las dificultades taxonómicas en torno a $C$. planetophorus, este taxón fue originalmente determinado como Coscinodiscus planetophorus Meister (Hendey, 1958), mismo que a su vez era confundido frecuentemente con Coscinodiscus asymmetricus Meister. La revisión detallada de ambas especies resultó en determinación de dos taxa distintos: Cymatodiscus planetophorus (Meister) Hendey 1958 y Cymatotheca weissflogii (Grunow) Hendey 1958. Aunque ambos se caracterizan por poseer una valva elíptica de tamaño similar (Tabla 1), C. planetophorus se diferencia de $C$. weissflogii por una zona hialina central con 1 a 3-4 areolas, areolas radiales que se hacen más pequeñas hacia los márgenes de la valva; además de un anillo marginal de fultopórtulas, usualmente dos en cada polo y dos sobre el margen, equidistantes a los polos (Figuras 7, 8). Estas diferencias merísticas y morfométricas se distinguen claramente en microscopía de luz y permiten discriminar con certidumbre entre los dos taxa.

Por otra parte, los intervalos de variación de los datos merísticos y morfométricos observados en los especímenes de este estudio corresponden con aquellos reportados en otras localidades (Tabla 1), no obstante que no se encontraron especímenes tan pequeños (12 $\mu \mathrm{m}$ de largo) como los reportados por Lehmkuhl et al. (2010: 320, Figura 26), ni tan grandes (23-30 $\mu \mathrm{m}$ de largo) como en Hendey (1958: Lám. V, Figura 8), Paulmier (1993: Lám. 35: Figura 7-8), o Tremarin et al. (2008: 1107, Figuras 1-2).

La mayoría de las observaciones sobre hábitos de $C$. planetophorus la ubican como forma planctónica, e.gr., Bainbridge (1963), Desikachary et al. (1987), Ricard (1987), Paulmier (1993), Lin y Yan (2007), Tremarin et al. (2008), Lehmkuhl et al. (2010), Costa-Böddeker et al. (2016) y Parizzi et al. (2016). También ha sido considerada epipélica (Hendey,1958; Sylvestre et al., 2004; Costa-Böddeker et al., 2016) y epífita (Foged, 1975; Sylvestre et al., 2004; Tremarin et al., 2008). Así, a pesar de que Sylvestre et al. (2004) y Parizzi et al. (2016) consideraron a C. planetophorus forma bentónica ellos la recolectaron en muestras de plancton; 
Parizzi et al. (2016), even though they collected it in plankton samples; whilst Costa-Böddeker et al. (2016) deemed it thycoplankton. Our observations confirm the benthic/thycoplanktic habits of $C$. planetophorus. In the present study $M$. curema a mullet and $C$. corteziensis an oyster were added to the list of species that feed on $C$. planetophorus together with the sea cucumber Holuthurian sp. (Foged, 1975) and a fish, Ethmalosa fimbriata Browdich (1825) (Bainbridge, 1963). Thus, assessment of its nutritional importance to commercial species should be considered, along with the ecological issues concerning this diatom species.

According to the recorded temperature range (23.3$31.8^{\circ} \mathrm{C}$ ), which like that reported by Bainbridge (1963), Costa-Böddeker et al. (2016) and Parizzi et al. (2016), C. planetophorus is considered of tropical affinity (ValenteMoreira \& Moreira-Filho, 1981; Ricard, 1987). Likewise, on the basis of salinity measurements, Valente-Moreira \& Moreira-Filho (1981) and Ricard (1987) proposed that $C$. planetophorus was a brackish-water form. However, it has also been recorded at salinities of 14.9 (Hendey, 1958), 0-14 (Tremarin et al., 2008) and 0.2-15 (Lehmkuhl et al., 2010). Thus, although C. planetophorus seems to tolerate a wide range of salinities, our observations (21.1-33) as in Costa-Böddeker et al. (2016) and Parizzi et al. (2016) fall within the range of brackish-marine conditions.

\section{Conclusions}

This is the first record of $C$. planetophorus from Mexican coasts and North America overall. It widens the distribution range of this taxon, inasmuch until now it was recorded only for South America (Paulmier, 1993; Sylvestre et al., 2004; Tremarin et al., 2008; Lehmkuhl et al., 2010), Asia (Desikachary et al., 1987; Lin \& Yan, 2007; Khustina et al., 2014; Costa-Böddeker et al., 2016) and Africa (Hendey, 1958; Bainbridge, 1963; Foged, 1975; Parizzi et al., 2016). This could be more related to the lack of comprehensive floristic studies worldwide than to other important taxonomic or biogeographical issues.

The confirmed benthic/thycoplanktic habits and brackish/marine water distribution of C. planetophorus in tropical environments provides a basis for further mientras que Costa-Böddeker et al. (2016) la consideraron ticoplancton. Nuestras observaciones confirman los hábitos bentónicos/ticoplanctónicos de C. planetophorus. En el presente estudio, la lisa $M$. curema y el ostión C. corteziensis, se incluyen a la lista de especies que se alimentan de $C$. planetophorus en conjunto con el pepino de mar Holuthurian sp. (Foged, 1975) y el pez Ethmalosa fimbriata Browdich (1825) (Bainbridge, 1963). Por lo que la valoración de su importancia nutricional para especies de valor comercial habría de considerarse, junto con aspectos ecológicos en torno a esta especie de diatomea.

De acuerdo con el intervalo de temperatura registrado en este estudio $\left(23.3-31.8^{\circ} \mathrm{C}\right)$, que, al igual que los registrados por Bainbridge (1963), Costa-Böddeker et al. (2016) y Parizzi et al. (2016), C. planetophorus es un organismo de afinidad tropical (Valente-Moreira \& Moreira-Filho, 1981; Ricard, 1987). Asimismo, con base en los valores de salinidad, Valente-Moreira \& Moreira-Filho (1981) y Ricard (1987) propusieron que C. planetophorus era una forma de aguas salobres, sin embargo, también ha sido registrado en salinidades de 14.9 (Hendey, 1958), 0-14 (Tremarin et al., 2008) y 0.215 (Lehmkuhl et al., 2010). Así, aunque C. planetophorus parece tolerar un amplio rango de salinidades, nuestras observaciones (21.1-33), al igual que las de CostaBöddeker et al. (2016) y Parizzi et al. (2016) lo ubican en condiciones salobres-marinas.

\section{Conclusiones}

Este es el primer registro de C. planetophorus para costas mexicanas y en general de América del Norte. De la misma manera, amplía el rango de distribución de este taxón, toda vez que hasta ahora solo había sido registrado para América del Sur (Paulmier, 1993; Sylvestre et al., 2004; Tremarin et al., 2008; Lehmkuhl et al., 2010), Asia (Desikachary et al., 1987; Lin \& Yan, 2007; Khustina et al., 2014; Costa-Böddeker et al., 2016) y África (Hendey, 1958; Bainbridge, 1963; Foged, 1975; Parizzi et al., 2016). Esto parece relacionarse más con la carencia de estudios florísticos comprensivos a nivel global que con otros aspectos biogeográficos o taxonómicos.

La confirmación de los hábitos bentónicos/ ticoplanctónicos de C. planetophorus y de su distribución en aguas salobres/marinas de ambientes tropicales representa una base para estudios posteriores que se enfoquen sobre la relevancia ecológica de este taxón 
studies focusing on the ecological importance of this taxon for fisheries management policies in these environments. Hence, it is shown that floristic studies of benthic diatoms in Mexican coasts in general are mandatory, inasmuch they unveil taxonomic problems such as the one reported here that underlines relevant ecological implications.

\section{Acknowledgements}

To CONACYT for the scholarship granted to the first author (CVU 623974). To the Project "Variaciones de la estructura de microalgas del medio y consumidas in situ por ostiones Crassostrea corteziensis" (SIP19154). To the support of Cooperativa de Ostioneros del Mar de Villa Juárez S.C. de R.L. de C.V. for supplying samples. We thank Carlos Romero Bañuelos and the Laboratorio de Contaminación y Toxicología AmbientalUAN; and Rosendo Balois, Apatzingan Palomino and Nancy Ruelas and the Laboratorio de Análisis Especiales de la Unidad de Tecnología de AlimentosUAN for lending the facilities and equipment for sample processing. Also, those who aided in field work and sample processing. DASB is COFAA and EDI fellow of the IPN. To the anonymous reviewers whose comments helped to improve this work. en torno a políticas de manejo de pesquerías en estos ecosistemas. Así, se demuestra la necesidad de llevar a cabo estudios florísticos de diatomeas bentónicas en general en las costas mexicanas, toda vez que revelan problemas taxonómicos como el que se aborda aquí, mismo que tiene relevantes implicaciones ecológicas.

\section{Agradecimientos}

A CONACYT por la beca otorgada al primer autor (CVU 623974). Al proyecto "Variaciones de la estructura de microalgas del medio y consumidas in situ por ostiones Crassostrea corteziensis" (SIP19154). A la cooperativa de Ostioneros del Mar De Villa Juárez S.C. de R.L. de C.V. por proporcionar muestras para el estudio. A Carlos Romero Bañuelos y el Laboratorio de Contaminación y Toxicología AmbientalUAN; a Rosendo Balois, Apatzingan Palomino y Nancy Ruelas y el Laboratorio de Análisis Especiales de la Unidad de Tecnología de Alimentos-UAN por facilitar las instalaciones y equipos necesarios para el procesamiento de muestras. A las personas que participaron en los muestreos y procesamiento de muestras. DASB es becario COFAA y EDI del IPN. A los revisores anónimos cuyos comentarios ayudaron a mejorar este trabajo.

\section{References}

Bainbridge, V. (1963). The food, feeding habits and distribution of the bonga Ethmalosa dorsalis (Curvier \& Valenciennes). Journal of Marine Science, 28(2), 270-284. https://doi.org/10.1093/icesims/28.2.270

Blanco-Correa, J. M., Flores-Verdugo, F., Ortiz-Pérez, M. A., De la Lanza-Espino, G., López-Portillo, J., ValdézHernández, I., Agraz-Hernández, C., Czitrom, S., Rivera-Arriaga, E., Orozco, A., Jiménez-Ramón, G.A., Benítez-Pardo, D., Gómez-Gurrola, J., González-Díaz, A.A., Soria-Barreto, M., Otis-Kruse, G., JacoboSapién, E.A., López-Cano, G., Blanco-Fuentes, H., \& Blanco-Fuentes, R. (2011). Diagnóstico funcional de Marismas Nacionales. Informe final de los convenios de coordinación entre la Universidad Autónoma de Nayarit y la Comisión Forestal con el patrocinio del Gobierno del Reino Unido. https://www.conafor.gob. mx:8080/documentos/docs/7/3920Diagn\%C3\%B3stico\%20Funcional\%20de\%20Marismas\%20Nacionales.pdf

CONANP. (2013). Programa de Manejo Reserva de la Biósfera Marismas Nacionales Nayarit. Secretaría de Medio Ambiente y Recursos Naturales. https://simec.conanp.gob.mx/pdf_libro_pm/77 libro_pm.pdf

Costa-Böddeker, S., Thuyen, L. X., Schwarz, A., Đức-Huy, H., \& Schwalb, A. (2016). Diatom assemblages in surface sediments along nutrient and salinity gradients of Thi Vai Estuary and Can Gio Mangrove Forest, Southern Vietnam. Estuaries and Coasts, 40, 479-492. https://doi.org/10.1007/s12237-016-0170-5

Desikachary, T. V., Hema, A., Prasad, A. K. S. K., Sreelatha, P. M., Sridharan, V. T., \& Subrahmanyan, R. (1987). Marine diatoms from the Arabian Sea and Indian Ocean. Ed. Madras Science Foundation.

Estrada-Gutiérrez, K. M., Siqueiros-Beltrones, D. A., \& Hernández-Almeida, O. U. (2017). New records of benthic diatoms (Bacillariophyceae) for Mexico in the Nayarit littoral found in gut contents of Crassostrea corteziensis (Mollusca: 
Bivalvia). Revista Mexicana de Biodiversidad, 88(4), 985-987. https://doi.org/10.1016/j.rmb.2017.10.039

Foged, N. (1975). Some Littoral Diatoms from the Coast of Tanzania. Ed. J. Cramer.

Guiry, M. D., \& Guiry, G. M. (2021). AlgaeBase. World-wide electronic publication, National University of Ireland, Galway. http://www.algaebase.org

Hendey, I. N. (1957). Marine Diatoms from some West African Ports. Journal of the Royal Microscopical Society, Series 3 , 77 (1/2), 28-85. http://doi.org/10.1111/j.1365-2818.1957.tb02015.x

Hernández-Almeida, O. U., Estrada-Gutiérrez, K. M., Siqueiros-Beltrones, D. A. \& Inda Díaz, E. A. (2019). Composición de especies de diatomeas en la dieta in situ del ostión de placer Crassostrea corteziensis en un sistema estuarino. Hidrobiológica, 29(3), 109-127. https://doi.org/10.24275/uam/izt/dcbs/hidro/2020v29n3/Hernandez

Jeffrey, S. W., Vesk, M., \& Mantoura, R. F. C. (1997). Phytoplankton pigments: windows into the pastures of the sea. Nature \& Resources, 33(2), 14-29. http://plymsea.ac.uk/id/eprint/3587

Kasim, M., \& Mukai, H. (2006). Contribution of benthic and epiphytic diatoms to clam and oyster production in the Akkeshi-ko estuary. Journal of Oceanography, 62, 267-281. https://doi.org/10.1007/s10872-006-0051-9

Khustina, Y. C., Duryadi-Solihin, D., \& Pratiwi, N. (2014). Morphological identification and diversity analysis of fossil diatoms from diatomite Sangiran Central Java Indonesia. Jurnal Biologi Indonesia, 10(2), 247-258. https://doi. org/10.14203/jbi.v10i2.2105

Lehmkuhl, E. A., Tremarin, P. I., Moreira-Filho, H., \& Veiga-Ludwig, T.A. (2010). Thalassiosirales (Diatomeae) da baía de Guaratuba, Estado do Paraná, Brasil. Biota Neotropica, 10(2), 313-324. https://doi.org/10.1590/S1676-06032010000200033

Lin, G., \& Yang, Q. (2007). Species diversity and the distribution of micro-phytoplankton in the Taiwan Strait. Biodiversity Science, 15(1), 31-45. https://doi.org/10.1360/biodiv.060103

López-Fuerte, F. O., \& Siqueiros-Beltrones, D. A. (2016). A checklist of marine benthic diatoms (Bacillariophyta) from Mexico. Phytotaxa, 283(3), 201-258. http://dx.doi.org/10.11646/phytotaxa.283.3.1

López-Fuerte, F. O., Siqueiros-Beltrones, D. A., \& Navarro, J. N. (2010). Benthic diatoms associated with mangrove environments in the northwest region of Mexico. Ed. CONABIO-UABCS-IPN. https://www.biodiversidad.gob. mx/publicaciones/versiones digitales/BenticDiatoms.pdf

MacIntyre, H. L., Geider, R. J., \& Miller, D. C. (1996). Microphytobenthos: the ecological role of the "secret garden" of unvegetated, shallow-water marine habitats. I. distribution, abundance and primary production. Estuaries, 19(2), 186-201. https://doi.org/10.2307/1352224

Martínez, A. M., Garzón-Cardona, J. E., \& Freije, R. H. (2013). Producción primaria en estuarios. In Marcovecchio, J. \& Freije, R. H. Procesos Químicos en Estuarios. (pp. 151-172). Ed. edUTecNe.

Martínez, Y. J., \& Siqueiros-Beltrones, D. A. (2018). New floristic records of benthic diatoms (Bacillariophyceae) from the Gulf of California. Hidrobiológica, 28(1), 141-145. https://doi.org/10.24275/uam/izt/dcbs/hidro/2018v28n1/Siqueiros

Parizzi, R. A., Machado, E. C., Tavares, C. P. S., Fernandes, L. F., De Camargo, M. G., \& Mafra, Jr. L. L. (2016). Primary productivity and phytoplankton dynamics in a subtropical estuary: a multiple timescale approach. Scientia Marina, 80(3), 291-303. https://doi.org/10.3989/scimar.04358.26A

Paulmier, G. (1993). Microplancton des eaux Marines et Saumâtres de la Guyane et des Antilles Françaises. Ed. l'ORSTOM.

Popovich, C. A., \& Guinder, V. A. (2013). El rol del fitoplancton en los procesos bioquímicos en estuarios. In Marcovecchio, J. \& Freije, R. H. Procesos Químicos en Estuarios. (pp. 173-197). Ed. edUTecNe.

Ricard, M. (1987). Atlas Du Phytoplancton Marin. Ed. Centre National de la Recherche Scientifique.

SAGARPA-CONAPESCA. (2010). Obras de dragado en el estero Pozo Chino en Santiago Ixcuintla, Nayarit. Manifestación de impacto ambiental. http://sinat.semarnat.gob.mx/dgiraDocs/documentos/nay/ estudios/2011/18NA2011H0001.pdf

Siqueiros-Beltrones, D. A. (2002). Diatomeas bentónicas de la Península de Baja California; diversidad y potencial ecológico. Ed. Oceánides-CICIMAR-IPN-UABCS.

Siqueiros-Beltrones, D. A., \& Argumedo-Hernández, U. (2015). Diatomeas epifitas consumidas por adultos de abulón (Haliotis spp.) en Baja California Sur, México. Revista Mexicana de Biodiversidad, 86(1), 111-122. https://doi. org/10.7550/rmb.47977

Siqueiros-Beltrones, D. A., \& Hernández-Almeida, O. U. (2006). Floristics of epiphytic diatoms in a patch of subtropical macroalgae. CICIMAR-Oceánides, 21(1-2): 11-61. https://www.researchgate.net/publication/236035768 
Siqueiros-Beltrones, D. A., \& Voltolina, D. (2000). Grazing selectivity of red abalone Haliotis rufescens postlarvae on benthic diatom films under culture conditions. Journal of the World Aquaculture Society, 31(2), 239-246. https://doi. org/10.1111/j.1749-7345.2000.tb00359.x

Siqueiros-Beltrones, D. A., Argumedo-Hernández, U., \& López-Fuerte, F. O. (2017). Diversity of benthic diatoms in the Guerrero Negro Lagoon (El Vizcaíno Biosfere Reserve), Baja California Peninsula, Mexico. Revista Mexicana de Biodiversidad, 88(1), 21-35. https://doi.org/10.1016/j.rmb.2017.01.026

Siqueiros-Beltrones, D. A., López-Fuerte, F. O., Hernández-Almeida, O. U., \& Argumedo-Hernández, U. (2011). Los manglares de la Península de Baja California. In Serviere-Zaragoza, Riosmena-Rodríguez \& Félix-Pico, E. F. Microalgas asociadas a sistemas de manglar. (pp. 155-180). Ed. Centro de Investigaciones Biológicas del Noroeste.

Sylvestre, F., Guiral, D., \& Debenay, J. P. (2004). Modern diatom distribution in mangrove swamps from the Kaw Estuary (French Guiana). Marine Geology, 208 (2-4), 281-293. https://doi.org/10.1016/j.margeo.2004.04.012

Tremarin, P. I., Veiga-Ludwig, T. A., \& Moreira-Filho, H. (2008). Thalassiosirales (Diatomeae) do rio Guaraguaçu, Bacia Litorânea, PR, Brasil. Acta Botánica Brasilica, 22(4), 1101-1113. http://dx.doi.org/10.1590/S010233062008000400021

Valente-Moreira, I. M., \& Moreira-Filho, H. (1981). Contribuição ao estudo das Bacillariophyceae (Diatomáceas) de Caiobá, Etado do Paraná, Brasil. Acta Biológica Paranaense, 10/11, 157-197. https://doi.org/10.5380/abpr.v10i0.938 